\title{
Targeting Colorectal Cancer Cells with a Functionalised Calix[4]arene Receptor: Biophysical Studies
}

\author{
Angela F Danil de Namor ${ }^{1, *}$, Nawal Al Hakawati ${ }^{2}$ and Sami Y Farhat ${ }^{3}$ \\ 1 Laboratory of Thermochemistry, Department of Chemistry, University of Surrey, \\ Guildford GU2 7XH, Surrey, UK \\ 2 Department of Biological Sciences, Faculty of Science, Beirut Arab University, Tripoli 1107-2809, Lebanon; \\ n.elhakawati@bau.edu.lb \\ 3 Dr. Suliman Habib Hospital, Dubai P.O. Box 500001, SZR, United Arab Emirates; samiyfarhat@yahoo.co.uk \\ * Correspondence: a.danil-de-namor@surrey.ac.uk; Tel.: +44-1483-689581
}

Citation: Danil de Namor, A.F.; Al Hakawati, N.; Farhat, S.Y. Targeting Colorectal Cancer Cells with a Functionalised Calix[4]arene Receptor: Biophysical Studies. Molecules 2022, 27, 510. https:// doi.org/10.3390/molecules27020510

Academic Editors: Vladislav Tomisic and Camillo Rosano

Received: 16 November 2021

Accepted: 10 January 2022

Published: 14 January 2022

Publisher's Note: MDPI stays neutral with regard to jurisdictional claims in published maps and institutional affiliations.

Copyright: (C) 2022 by the authors. Licensee MDPI, Basel, Switzerland. This article is an open access article distributed under the terms and conditions of the Creative Commons Attribution (CC BY) license (https:// creativecommons.org/licenses/by/ $4.0 /)$.

\begin{abstract}
Colorectal cancer (CRC) is a disease which is causing a high degree of mortality around the world. The present study reports the antiproliferative impact of the thioacetamide calix[4]arene, CAII receptor on a highly differentiated Caco-2 cell line. This statement is corroborated by the MTT assay results which revealed a reduction in the cell viability with an IC50 value of $19.02 \pm 0.04 \mu \mathrm{M}$. Microscopic results indicated that at the starting amount of $10 \mu \mathrm{M}$ of CAII, a decrease in cells confluency can already be observed in addition to changes in cells morphology. Cell metabolic pathway changes were also investigated. ${ }^{1} \mathrm{H}$ NMR findings showed downregulation in lactate, pyruvate, phosphocholine, lipids, and hydroxybutyrate with the upregulation of succinate, indicating a decline in the cells proliferation. Some biochemical alterations in the cells as a result of the CAII treatment were found by Raman spectroscopy.
\end{abstract}

Keywords: thioacetamide calix[4]arene; colorectal cancer; ${ }^{1} \mathrm{H}$ NMR; Raman

\section{Introduction}

Colorectal cancer (CRC), also known as bowel cancer, affects over 1.93 million people worldwide and has led to almost 935,000 deaths according to the report published by the World Health Organization (WHO) in March 2021. It is the third most commonly detected malignancy and the fourth global killer among cancers [1]. As far as Europe is concerned, CRC is the most common cause of death after lung cancer [2], while in the United Kingdom this disease occupies the third position after breast and lung cancer, as recently reported by the National Health Service [3]. As the world population increases, CRC incidence is expected to increase by $60 \%$, with more than 2.2 million new cases and 1.1 million deaths by 2030 [4]. However, while improvements in perioperative care along with chemotherapy or radiotherapy will help in decreasing the CRC mortality [5], the scope of these treatments is limited due to (i) their non-selective nature since they target not only cancer cells, but also healthy ones, and (ii) other side effects encountered during and after treatment [6-9]. The major drawbacks in these therapies have led to extensive studies in the last three decades aimed at designing selective anticancer agents targeting only cancer cells such as those based on nanotechnology, surface modifications of polymer drugs, and the use of cancer biomarkers [7]. Therefore, it is of outmost importance to address the issue of selectivity in the design of anticancer agents. Given that this is one of the main features of supramolecular chemistry, receptors such as cyclodextrins, crown ethers, calixarenes, and their derivatives have shown a great potential for biomedical applications. Calixarenes have received particular attention in the pharmaceutical field as active anticancer, antidiabetic, anti-obesity [8], and antibacterial agents [9]. Thus, studies on their anticancer properties have been the subject of several research groups [10,11], where investigations in vitro against different types of cancer cell lines were conducted. 
Baggetto and co-workers [12] have synthesised a number of calix[4]arene-based compounds (calix[4]arene dihydroxyphosphonic acid, $p$-tert-butyl calix[4]arene dihydroxyphosphonic acid, and para-octanoyl calix[4]arene dihydroxyphosphonic acid) against different brain, breast, liver, blood, and skin cancer cells (MU2, MU2F, HT 1080, SP6.5, IPC227, Jurkat, MEWO, H1-60, Huh7, Hep-G2). The anticancer activity of these macrocycles has been compared to standard anticancer drugs. The outcome of their research revealed that these calix[4]arene derivatives have a potent anticancer activity, especially in melanoma cells (skin cancer) and lymphoblastic leukaemia cells. Similarly, other research groups have tested a calix[4]arene functionalised with four platinum (II) centres on non-small cell lung, breast, and hepatocellular cancer, showing that these compounds offer a better activity than carboplatin (chemotherapeutic drug) [13]. Several reports on a wide range of calixarene derivatives highlighted their remarkably low degree of toxicity [14-17], to the extent that studies on $p$-sulphonatocalix[4]arene have shown the compound to have zero toxicity toward normal healthy blood cells in concentration levels up to $5 \mathrm{mmol} \mathrm{dm}^{-3}$ in vitro and in vivo at doses up to $100 \mathrm{mg} \mathrm{kg}^{-1}$ [18]. Few studies have been conducted in vivo on the applications of calix[4]arene derivatives in mammalian models (cancer mice models). Huliková and co-workers [19] examined the effect of glycol-conjugates of calix[4]arene in a B16F10 mouse melanoma model, where a significant reduction in tumour growth was observed within two weeks. As for clinical investigations, a US clinical trials database recorded one test started in 2012 using a calix[4]arene-based compound as angiogenesis antagonist with no reported results [9].

Metabolomics approaches have been recently developed as complementary technologies to genomic and proteomic fields [20,21], enabling the identification of products from biochemical reactions, and therefore information about metabolic pathways within the cell [22] can be obtained. Moreover, cell metabolites and biomolecules can be identified, thus providing a full metabolic fingerprint of the tested living cell. Despite the above-mentioned research efforts, to our knowledge there is no work reported in the literature regarding the use of functionalised calixarene receptors in colon carcinoma Caco-2 cells (colorectal cancer). Therefore, the aim of this investigation is to assess the bioactive impact of a calix[4]arene derivative, namely 5,11,17,23-tetra-tert-butyl[25,27bis(diethylthiocarbamoyl)oxy]calix[4]arene (CAII) (Figure 1), on this type of cancer cell line using a variety of techniques.

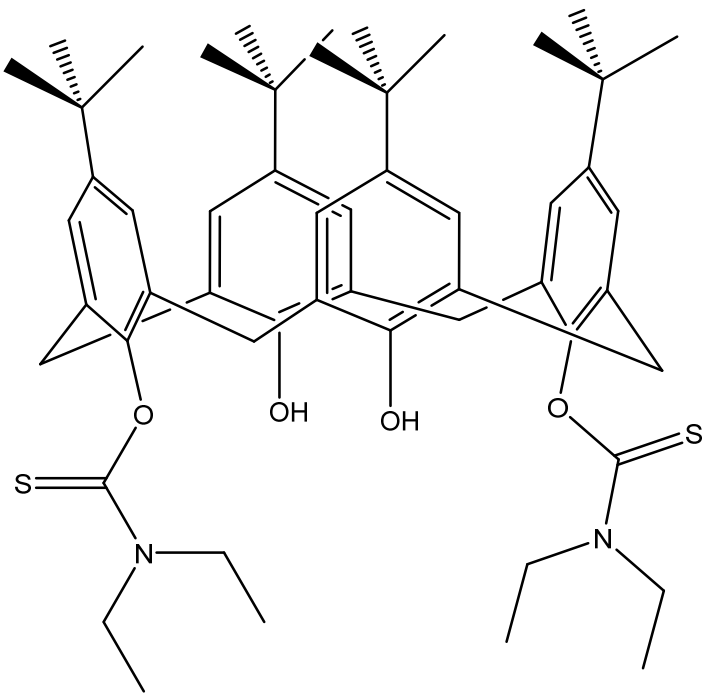

Figure 1. 2D structure of 5,11,17,23-tetra-tert-butyl[25,27-bis(diethylthiocarbamoyl)oxy]calix[4]arene, CAII. 


\section{Materials and Methods}

\subsection{Materials}

The cell line used throughout the study of Caco-2 (human colorectal adenocarcinoma) was obtained from the European Collection of Cell Cultures (ECACC), Porton Down, UK (Culture Collections, 2013). The culture medium and reagents Dulbecco's Modified Eagle Medium (DMEM); heat inactivated foetal bovine serum (FBS); MEM non-essential amino acids solution (NEAA) $(10 \mathrm{mM}), 0.5 \%$ trypsin-EDTA solution, L-glutamine solution $\left(0.2 \times 10^{-3} \mathrm{~mol} \mathrm{dm}^{-3}\right), 10,000 \mathrm{U} / \mathrm{mL}$ penicillin $/ 10,000 \mu \mathrm{g} / \mathrm{mL}$ streptomycin (antibiotic); and Dulbecco's phosphate-buffered saline (DPBS) $(1 \times) \mathrm{Ca}^{2+} / \mathrm{Mg}^{2+}$ free were purchased from Invitrogen Ltd. (Paisley, UK). 5-Diphenyltetrazolium bromide (MTT) and dimethyl sulfoxide (DMSO) were obtained from Sigma-Aldrich, Ltd. (Poole, UK). Staurosporine from Streptomyces sp. and an Annexin V-FITC Apoptosis Detection Kit were purchased from Abcam and deuterium oxide $\left(\mathrm{D}_{2} \mathrm{O}\right)(\mathrm{D}, 99.9 \%)$ from Cambridge Isotope Laboratories, Inc, Tewksbury, Massachusetts, United States.

\subsection{Synthesis of Thioacetamide Calix[4]arene Derivative,}

\section{5,11,17,23-Tetra-Tert-Butyl[25,27-bis(Diethylthiocarbamoyl)oxy]calix[4]arene, CAII}

The receptor was previously prepared by Danil de Namor and Pawlowski [23] and the synthetic procedure used for its preparation is described in the Supplementary Information.

\subsection{Cell Culture}

Caco-2 cells were cultured in Dulbecco's Modified Eagle's medium (DMEM), which is high in glucose $\left(25 \mathrm{mmol} \mathrm{dm}{ }^{-3}\right)$, supplemented with $4 \mathrm{mmol} \mathrm{dm}{ }^{-3}$ L-glutamine, $1 \%$ penicillin/streptomycin, 10\% foetal bovine serum (FBS), and 1\% non-essential amino acids (NEAA). The cells were maintained at $37{ }^{\circ} \mathrm{C}$ in a culture incubator in a $5 \% \mathrm{CO}_{2} / 95 \%$ air atmosphere. They were sub-cultured to approximately $80-90 \%$ confluence and afterwards they underwent passaging.

\subsection{CAII Treatment}

Caco-2 cells were seeded in 96-well plates with a density of $1 \times 10^{4}$ cells/well in $0.2 \mathrm{~cm}^{3} /$ well of a culture medium. Following overnight incubation to allow cell attachment, the culture medium was discarded and treatment with different concentrations of CAII ( 1 , $5,10,20,50,70$, and $100 \mu \mathrm{M}$ ) was applied with a total volume of $0.2 \mathrm{~cm}^{3} /$ well of serum-free medium incubated for 24 or $48 \mathrm{~h}$. Then, cells were harvested and submitted for cell toxicity determination flow cytometry and ${ }^{1} \mathrm{H}$ NMR analyses.

\subsection{CAII Preparation}

The compound was prepared in a minimum volume of dimethyl sulfoxide which did not exceed $0.1 \%(v / v)$, after which dilutions were made in DMEM according to the investigated concentrations. Cultures were checked microscopically (Zeiss TELAVAL inverted light microscope) during the treatment for changes in the cells' morphology.

\subsection{Cell Viability}

The count of viable cells was determined by the MTT (3-(4, 5-dimethylthiazolyl-2)-2, 5-diphenyltetrazolium bromide) assay. The first step of the procedure was the aspiration of the spent medium following the treatment period. Fresh, serum-free medium containing MTT $\left(0.5 \mathrm{mg} / \mathrm{cm}^{3}, 0.2 \mathrm{~cm}^{3} /\right.$ well $)$ was added to each well and incubated at $37^{\circ} \mathrm{C}$ for $150 \mathrm{~min}$. Following the incubation period, the medium containing MTT was discarded and the obtained formazan precipitate was dissolved in DMSO $\left(0.2 \mathrm{~cm}^{3}\right)$. The absorbance was measured at $570 \mathrm{~nm}$ using a SPECTROstar absorbance 96-well microplate reader (Omega Software, BMG LABTEACH, Aylesbury, UK) (Lambda 25, Perkin Elmer, Cambridgeshire, 
UK). The cell viability (percentage) of three or more dependent and independent experiments was calculated using the following equation (Equation (1)):

$$
\text { Cell viability }(\%)=(\mathrm{OD} \text { of treated cells }) /(\mathrm{OD} \text { of control cells }) \times 100 \%
$$

where OD is the notation used to indicate the optical density of the culture.

\subsection{Apoptosis Analysis by Annexin V-FITC Staining}

Caco- 2 cells $\left(1 \times 10^{6}\right.$ cells $/ 5 \mathrm{~cm}^{3} /$ flask $)$ were seeded in $25 \mathrm{~cm}^{2}$ flasks followed by the treatment of CAII $(10 \mu \mathrm{M})$. When cells reached $50 \%$ confluence, they were washed with PBS $\left(2 \mathrm{~cm}^{3}\right)$ after which they were incubated for $24 \mathrm{~h}$ at $37^{\circ} \mathrm{C}$ in a humidified atmosphere with $\mathrm{CO}_{2}(5 \%)$. Cell pellets were then re-suspended in a binding buffer $(500 \mu \mathrm{L},(1: 10))$ mixed with Annexin V-FITC and propidium iodide and incubated in a dark area at room temperature $\left(22 \pm 2{ }^{\circ} \mathrm{C}\right)$ for 5 to $10 \mathrm{~min}$. The samples were kept in ice until they were analysed using an Applied Biosystems ${ }^{\mathrm{TM}}$ Attune NxT Flow Cytometer (Thermo Fisher Scientific, Waltham, MA, USA). The quantitative measurement of cells undergoing death was determined. Forward and side scatters were used for gating to exclude cell debris. Fluorescence emission was detected in the FL-1 channel $(519 \mathrm{~nm})$ for cells labelled with Annexin V-FITC and in the FL-2 channel $(617 \mathrm{~nm})$ for cells labelled with PI. For each experimental sample, a total of 10,000 events were acquired for Annexin V-FITC and PI.

\subsection{Structural Insights on the CAII and Caco-2 Interactions Using ${ }^{1} H$ NMR Measurements}

Samples (Caco-2 cells and Caco-2 cells treated with CAII) were cultured as described above. The cells were exposed to the receptor $(10 \mu \mathrm{M})$ for a period of $24 \mathrm{~h}$. Then, Caco-2 cells were collected and suspended in $1 \times$ cold phosphate-buffered saline. The samples were rinsed twice with PBS and PBS mixed with deuterium oxide (NMR solvent) to minimise the NMR signal interference with water. Samples were transferred into $5 \mathrm{~mm}$ NMR tubes using DSS (4,4-dimethyl-4-silapentane-1-sulfonic acid) internal standard $\left(\delta_{\mathrm{H}}=0.00 \mathrm{ppm}\right)$. All ${ }^{1} \mathrm{H}$ NMR spectra were recorded at $298 \mathrm{~K}$ on a Bruker DRX-500 pulse Fourier transform NMR spectrometer. Following the ${ }^{1} \mathrm{H}$ NMR runs, spectra were collected and the signals of the cell chemical groups were assigned to identify its metabolic profile. Moreover, the interaction mechanism with CAII was determined from the obtained chemical shifts.

\section{9. ${ }^{1} \mathrm{H}$ NMR Spectroscopy of Caco-2 Cell Extracts}

${ }^{1} \mathrm{H}$ NMR studies were carried out at the University of Surrey to identify the different metabolites in the Caco-2 samples. These measurements were taken at $298 \mathrm{~K}$. The operating conditions included a pulse or flip angle of $30^{\circ}$, spectra width (SW) of $15 \mathrm{ppm}$, spectral frequency (SF) of $500.150 \mathrm{MHz}$, delay time of $0.3 \mathrm{~s}$, acquisition time (AQ) of $3.17 \mathrm{~s}$, and line broadening of $0.3 \mathrm{~Hz}$. All ${ }^{1} \mathrm{H}$ NMR spectra were processed and base-line corrected using ACD/NMR Processor 12.

\subsection{Confocal Raman Microscopy Studies}

Caco-2 cells were cultured and seeded with CAII using the procedure described in Section 2.3. However, only a $24 \mathrm{~h}$ incubation period was used in this study. Cells were fixed in paraformaldehyde (4\%), after which they were submerged in PBS (phosphate-buffered saline) prior to analysis. The samples were analysed using an inVia ${ }^{\mathrm{TM}}$ Confocal Raman Microscope (Renishaw, New Mills, UK) with a Nd:YAG laser (532 nm, frequency-doubled laser) with an output power of $40 \mathrm{~mW}$ and excitation spot of around $1 \mu \mathrm{m}$. A GaAlAs laser (wavelength $782 \mathrm{~nm}$ ) was used for excitation, producing a maximum of $9 \mathrm{~mW}$ at the focal plane of a $50 \times$ objective, typically used to illuminate the sample. Measurements were carried out at a spectral resolution of $4 \mathrm{~cm}^{-1}$. 


\subsection{Statistical Analysis}

Data are presented as the mean $\pm \mathrm{SD}$. Analyses were conducted using a one-way analysis of variance (ANOVA) and $p<0.05$ was considered to be statistically significant.

\section{Results and Discussion}

\subsection{CAII Cytotoxicity against Caco-2 Cell Viability}

The dose effect of CAII on Caco-2 cells viability was examined colorimetrically using 3-(4,5-dimethylthiazol-2-yl)-2,5-diphenyltetrazolium bromide (MTT) assay. Cells were treated with different concentrations of the receptor $(1$ to $100 \mu \mathrm{M})$ for $24 \mathrm{~h}$, after which the minimal inhibitory concentration $\mathrm{IC}_{50}$ (the concentration of the drug that reduces $50 \%$ of the cell viability) was determined. Analysis of the dose response viability inset (Figure 2) shows a significant decrease in the percentage of cell proliferation from $98 \%$ at $5 \mu \mathrm{M}$ to $9 \%$ at $50 \mu \mathrm{M}$ of CAII compared to control cells; therefore, an extended period of incubation was not required ( 48 or $72 \mathrm{~h}$ ) since more than $90 \%$ of the cells' growth was inhibited after $24 \mathrm{~h}$. The $\mathrm{IC}_{50}$ value for these cells was $19.02 \pm 0.04 \mu \mathrm{M}$, suggesting that the cytotoxic effect of the tested calix[4]arene derivative was prominent against the Caco-2 cell line.

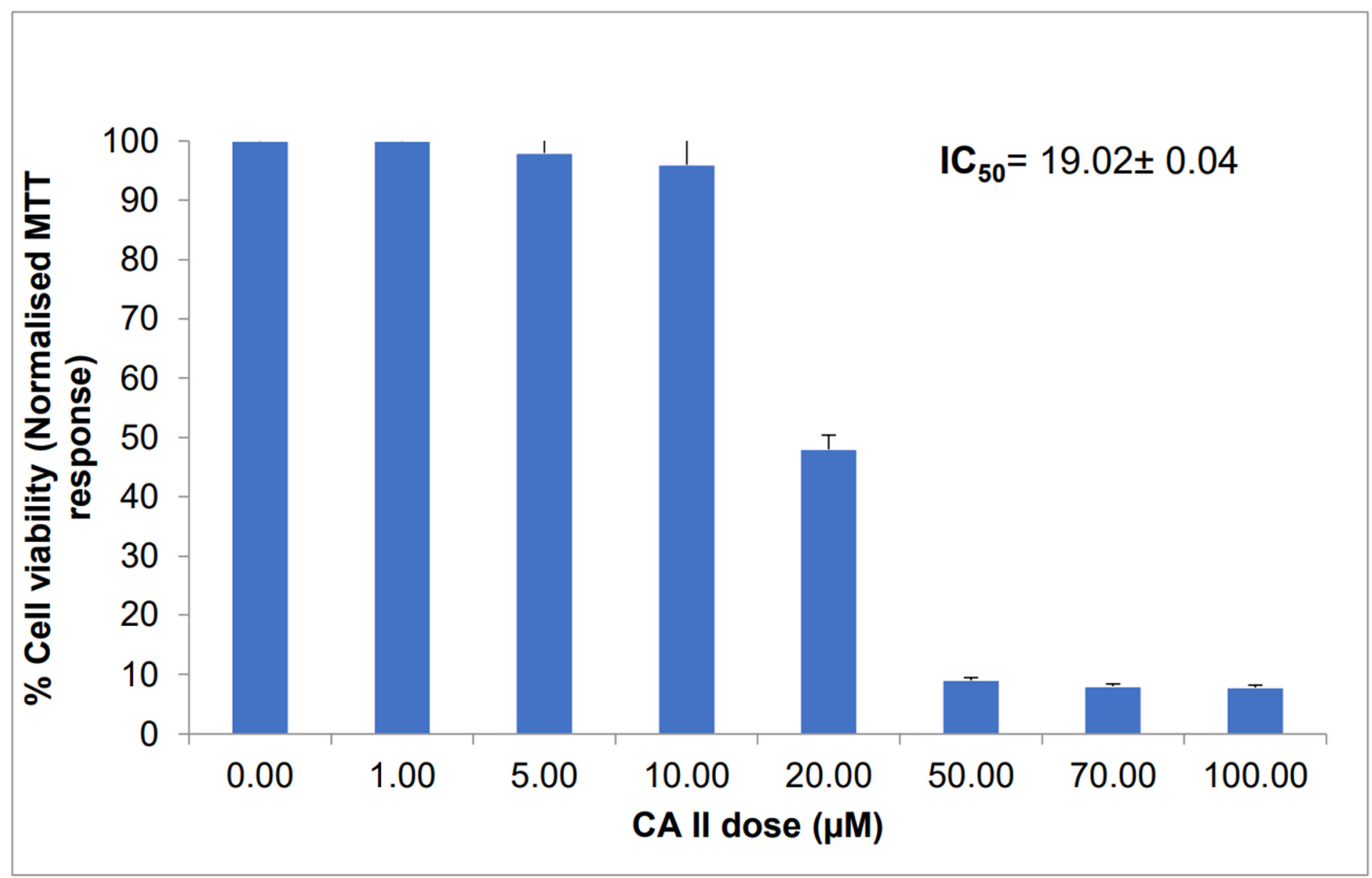

Figure 2. Dose effect of CAII on colon cancer cell viability (Caco-2) after $24 \mathrm{~h}$ incubation. Data are shown as mean \pm SEM ( $n=3$ dependent and independent experiments). Data analysis was performed using one-way ANOVA followed by Bonferroni post-test, $p<0.05$ versus CAII.

\subsection{CAII Inducing Death on Caco-2 Cells}

The outcome of the cytotoxicity assay provides strong evidence of the intensive effect of the CAII receptor on Caco-2 cells at high concentrations $(\sim 25-50 \mu \mathrm{M})$ after $24 \mathrm{~h}$ of exposure. As far as the effect of the receptor at lower concentrations on Caco-2 cells is concerned, this was further investigated by using cell death assay. Inducing apoptosis in 
cancer cells has been recognized as the most recommended strategy in the application of anticancer agents [24].

The results displayed in Figure 3 show the percentage of apoptotic cells (48.3\%) treated with CAII $(10 \mu \mathrm{M})$ for $24 \mathrm{~h}$ vs. $6.68 \%$ for untreated Caco- 2 cells, reflecting the effect of CAII on inducing apoptosis in the investigated cancer cells. Many studies have demonstrated that apoptosis is the best way to get rid of pre-cancerous or cancerous cells [25].

(a) $0 \mu \mathrm{M}$ CA-thioacetamide

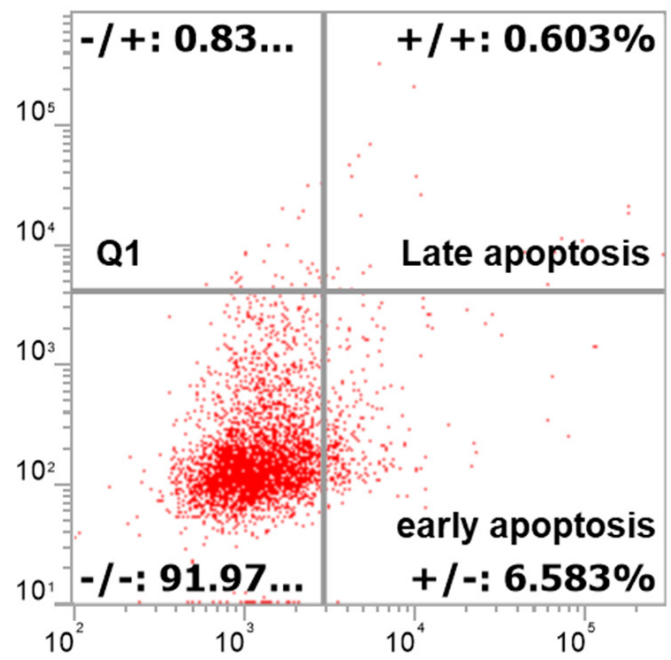

\section{(b) $10 \mu \mathrm{M}$ CA-thioacetamide}

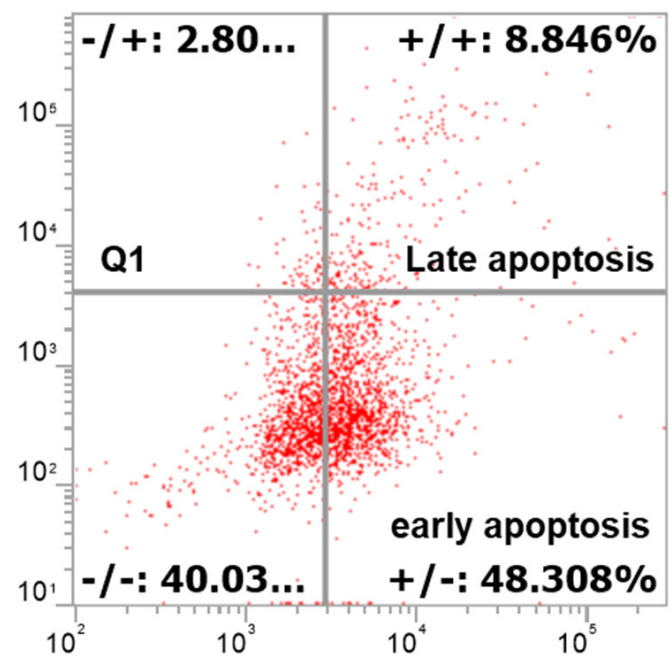

Figure 3. Histogram depicts apoptosis induction with CAII on Caco-2 using flow cytometry technique after $24 \mathrm{~h}$ incubation. Scatter plots (a,b) represent (a) untreated cells with $0 \mu \mathrm{M}$ CAII and (b) cells treated with $10 \mu \mathrm{M}$ CAII. Cells were stained with propidium iodide (PI) and Annexin V-FITC (AV). Live cells = are living unaffected cells; early apoptotic = cells binding Annexin V; late apoptotic = cells binding Annexin V and PI; Q1 indicates necrotic cells due to mechanical damage binding propidium iodide.

\subsection{Morphological Changes of Caco-2 Cells Induced by CAII Treatment}

Morphological and density changes of Caco-2 cells in response to CAII treatment during the $24 \mathrm{~h}$ incubation period were investigated using phase-contrast and bright field microscopy; micrographs are shown in Figures 4 and 5. As shown in Figure 4A, the control Caco-2 live cells appear to be more confluent. However, this confluency decreases with increasing concentrations of CAII. Interestingly, in addition to a lower cell density, morphological changes of the cells were observed with CAII treatment $(10 \mu \mathrm{M})$ (Figure 5B) when compared with untreated cells (Figure 5A).

For viewing the cells in 3D cultures, laser confocal scanning microscopy was applied, as it has been recognised as a well-established approach with a high resolution, sensitivity, and a penetration depth of up to several millimetres [26]. Figure 6 shows the 3D topographical images of the Caco-2 and receptor-treated cells. Inspection of the micrograph (Figure 6a) reveals the presence of well differentiated cells with a clear cell membrane (red contour) and inner cellular compartments (blue regions). Dramatic changes in the cell morphology were detected following the treatment with CAII (Figure 6b), where disruptions in the cell boundary (membrane) in addition to changes in the redistribution of the intracellular compartments (blue region) were observed, which could be due to the shedding or loss of the cellular material [27]. 


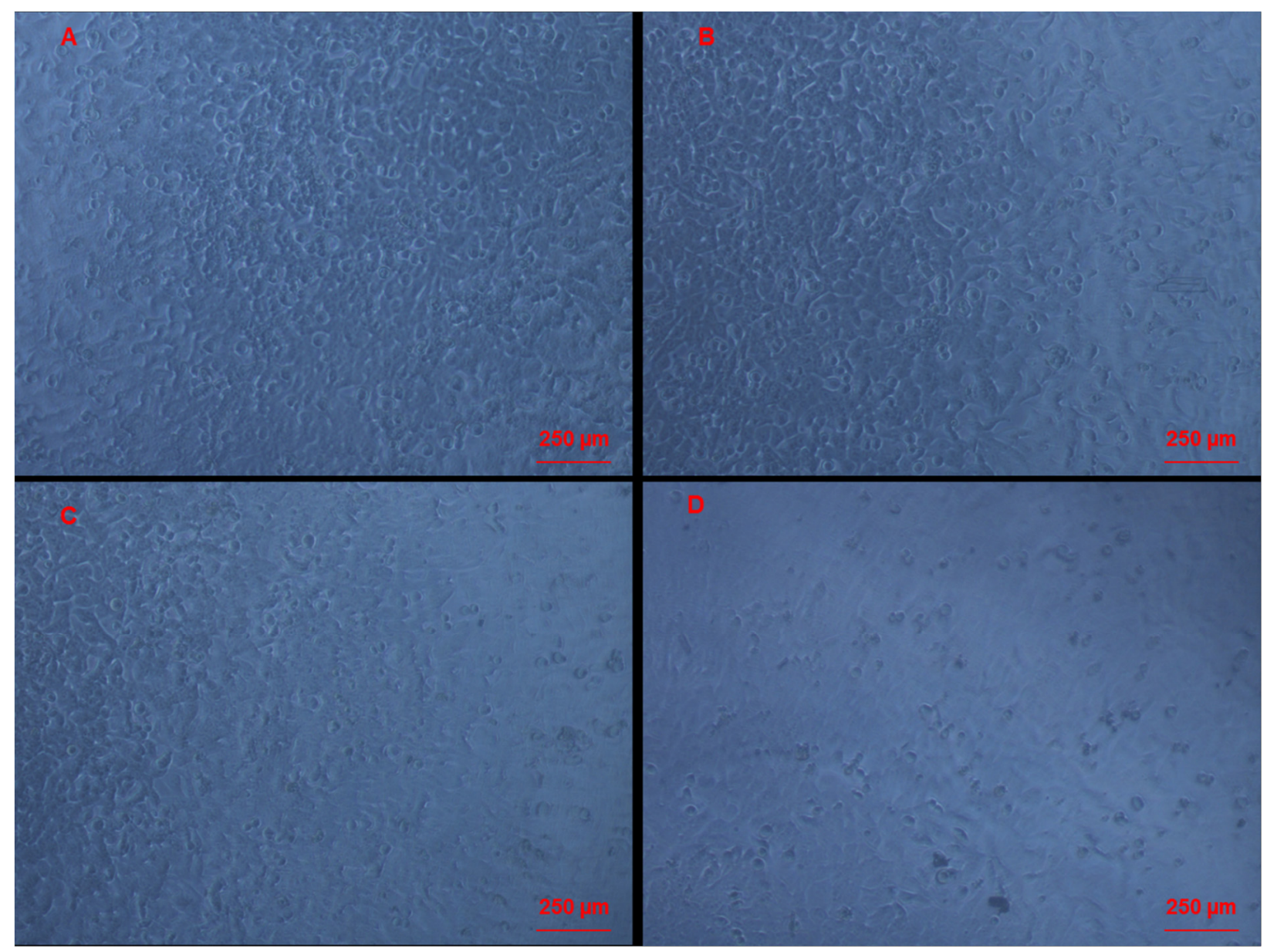

Figure 4. Caco-2 cells observed under the inverted phase-contrast microscope $24 \mathrm{~h}$ after being treated with different concentrations of CAII: (A) control cells, $0 \mu \mathrm{M}$ CAII; (B) cells treated with $10 \mu \mathrm{M}$ of CAII; (C) cells treated with $20 \mu \mathrm{M}$ CAII; and (D) cells treated with $50 \mu \mathrm{M}$ CAII. Magnification $\times 10$.
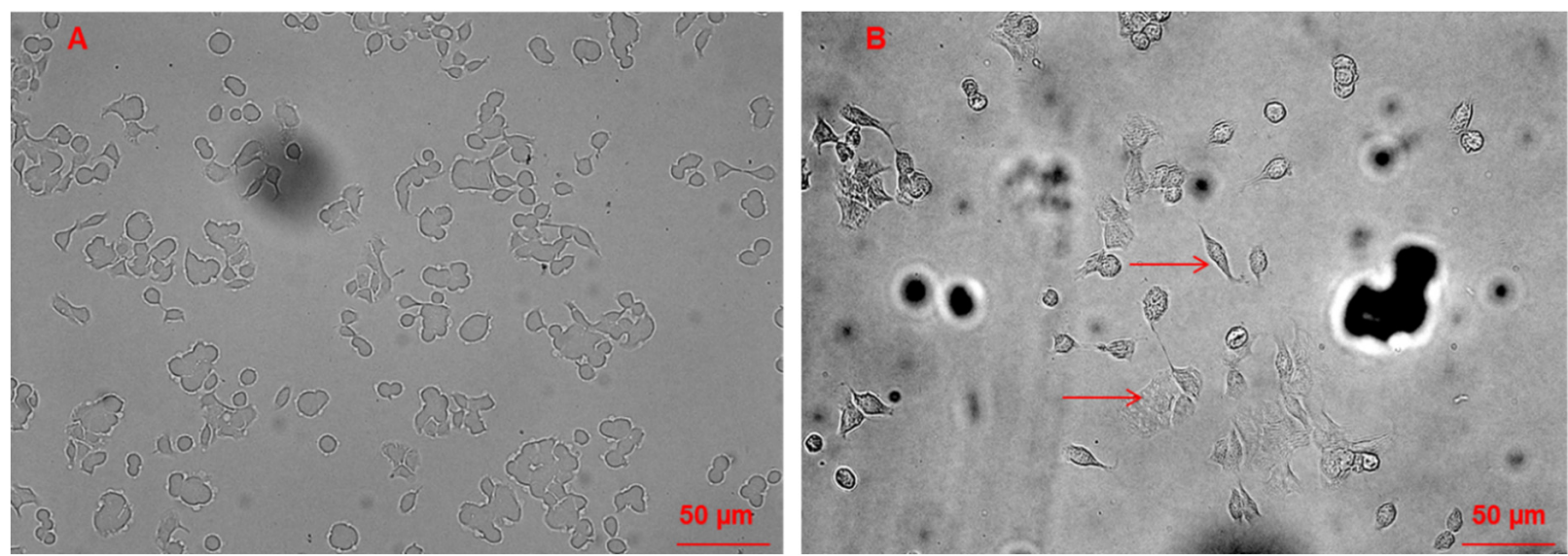

Figure 5. Bright-field micrographs of (A) Caco-2 cells and (B) Caco-2 cells incubated with $10 \mu \mathrm{M}$ CAII for $24 \mathrm{~h}$. 


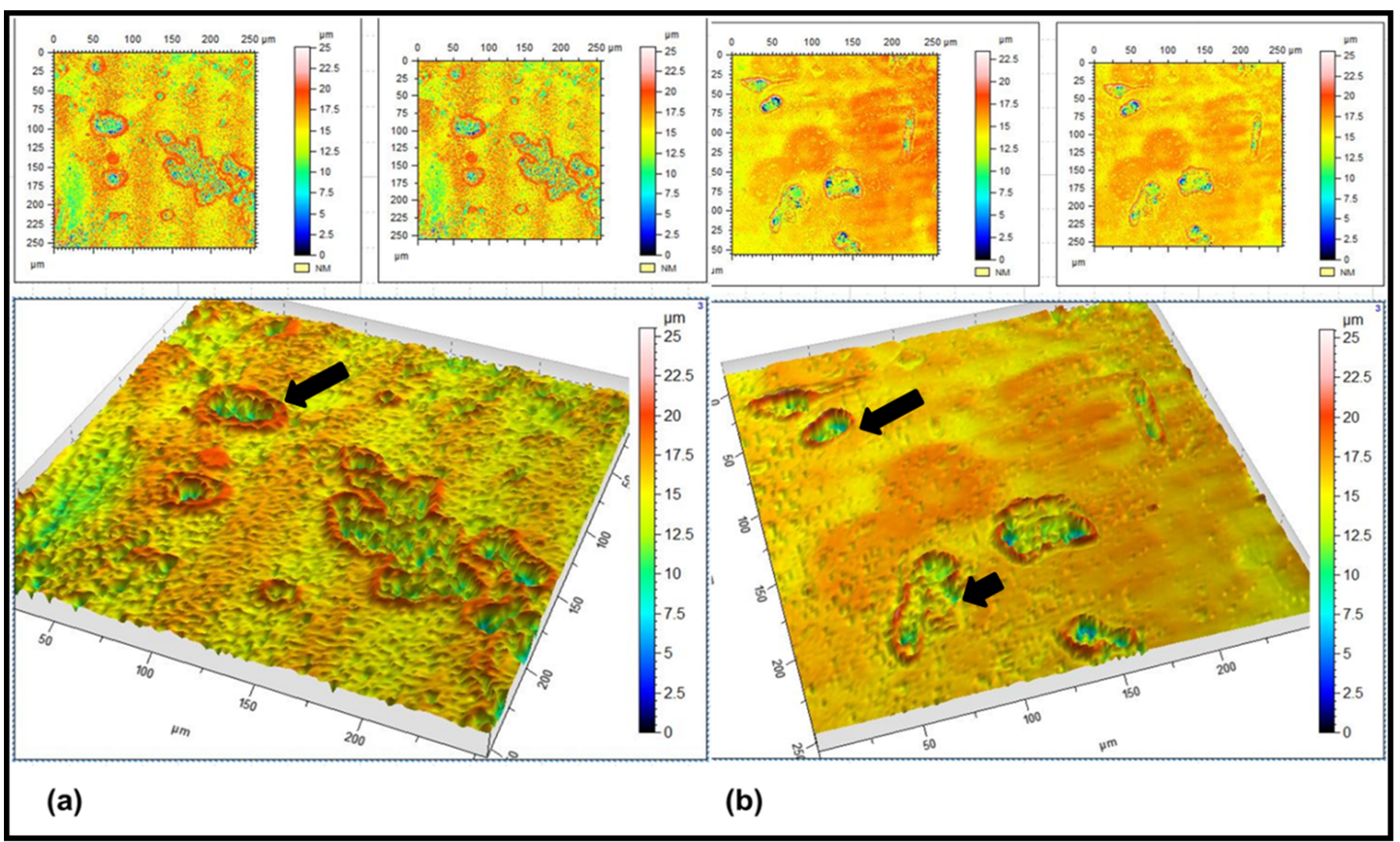

Figure 6. 3D Laser scanning confocal microscope topography images of (a) Caco-2 cells and (b) CAII-treated Caco-2 cells. (a,b) A view from the top. Cell inner compartments are given in blue. The $3 \mathrm{D}$ shape of the cells is shown by red contour lines.

This finding triggers a question about the mechanism of action of CAII on the metabolic pathways of the cells. One-dimensional ${ }^{1} \mathrm{H}$ NMR analysis was conducted to determine the metabolic fingerprint of the treated and untreated cancer cells.

\subsection{Metabolite Analysis of Untreated and CAII-Treated Caco-2 Cells Using ${ }^{1}$ H NMR Spectroscopy}

The proton NMR approach has been used in several studies due to its capability of detecting biomolecular compounds with a high reproducibility [28-31]. ${ }^{1} \mathrm{H}$ NMR analyses of differentiated cells of Caco-2 and Caco-2 treated with CAII were conducted. Several biomolecules were found in the obtained spectra. Metabolic status along with some potential metabolic markers in the samples was identified using the Human Metabolome Database, version 3.0 [32]. Initially, signals for the most significant metabolites, presented in the region of $\delta 5.00-0.80 \mathrm{ppm}$, were observed (Figure 7 and Table 1), including glucose, amino acids, phospholipids, tricarboxylic acid intermediates, and other metabolites. Some metabolites were not fully identified due to their overlap with other signals. Overall, thirty-two metabolites were identified as Caco-2 cellular constituents. 


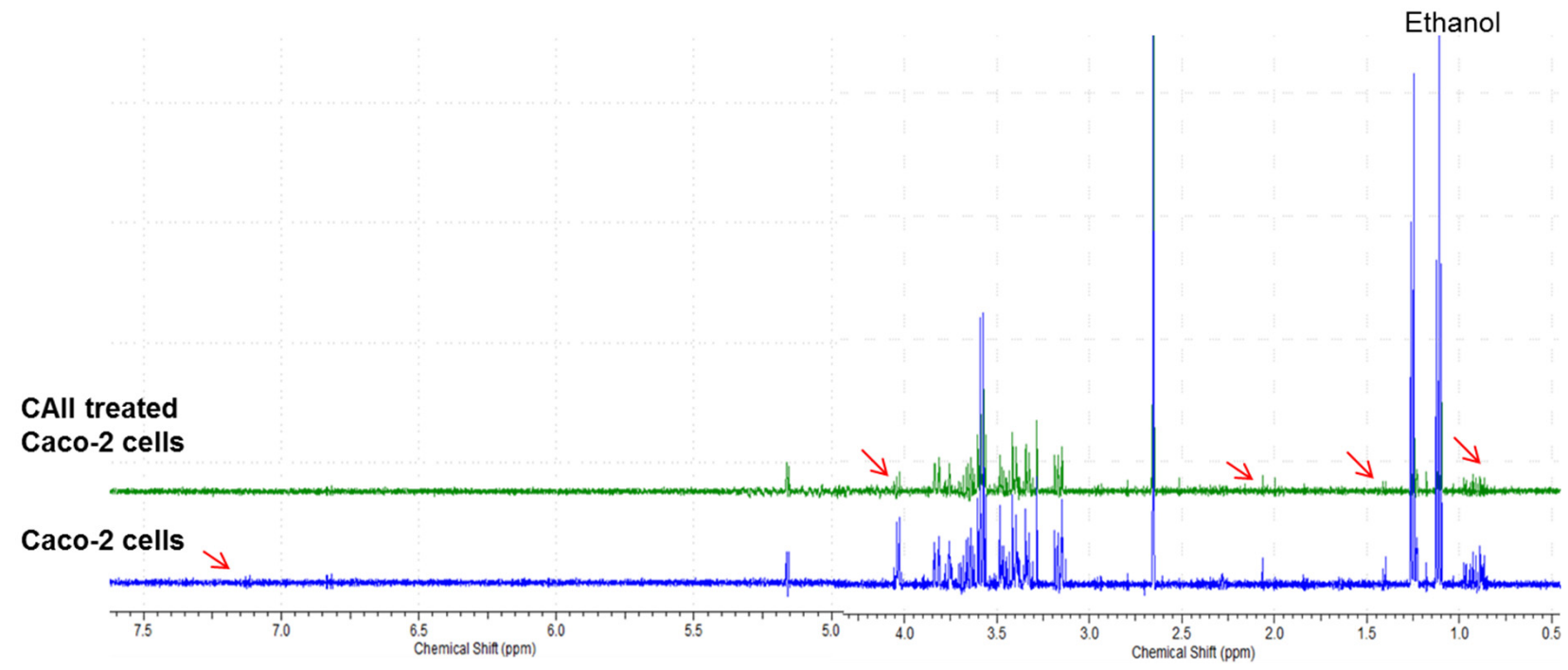

Figure 7. ${ }^{1} \mathrm{H}$ NMR of differentiated Caco-2 cells and CAII-treated Caco-2 cells in $\mathrm{D}_{2} \mathrm{O}$ showing extracellular metabolites. Number of scans was 132. Region between 5 and 4.20 ppm was omitted due to water suppression.

Table 1. ${ }^{1} \mathrm{H}$ NMR assignments of the major identified metabolites in Caco-2 and CAII-treated Caco-2 cells.

\begin{tabular}{|c|c|c|c|}
\hline $\begin{array}{l}\text { Metabolite } \\
\text { Number }\end{array}$ & Metabolites & $\begin{array}{c}\text { Caco-2 } \\
\text { Chemical Shifts (ppm) }\end{array}$ & $\begin{array}{c}\text { >Caco-2 Treated with CAII } \\
\text { Chemical Shifts (ppm) }\end{array}$ \\
\hline 1 & Lactate & $1.33,4.12$ & - \\
\hline 2 & Acetate & 1.91 & 1.91 \\
\hline 3 & Glutamine & $2.12,2.16,2.45$ & $2.12,2.16$ \\
\hline 4 & Glutamate & $2.05,2.36$ & $2.05,2.36$ \\
\hline 5 & VLDL & $0.88,1.29$ & $0.88,1.29$ \\
\hline 6 & LDL & 0.84 & - \\
\hline 7 & Glycoprotein & - & 2.10 \\
\hline 8 & Lysine & $1.44,1.75,3.02,3.76$ & $1.44,1.75,3.76$ \\
\hline 9 & Asparagine & $2.94,3.95$ & $2.94,3.95$ \\
\hline 10 & Creatinine & $3.04,3.93$ & - \\
\hline 11 & Methionine & 2.14 & - \\
\hline 12 & $\alpha$-Glucose & $3.45,3.54,3.71,3.73,3.85$ & $3.45,3.54,3.71,3.73,3.85$ \\
\hline 13 & $\beta$-Glucose & $3.23,3.43,3.49,3.90$ & $3.43,3.49,3.90$ \\
\hline 14 & Glycine & 3.56 & 3.56 \\
\hline 15 & Myo-Inositol & $3.55,3.63,4.07$ & $3.55,3.63,4.07$ \\
\hline 16 & Taurine & 3.27 & - \\
\hline 17 & Glycerophosphocholine & 3.24 & - \\
\hline 18 & Glutathione & $2.57,2.97$ & $2.57,2.97$ \\
\hline 19 & Threonine & $1.34,4.27$ & 1.34 \\
\hline 20 & Succinate & 2.39 & - \\
\hline 21 & Alanine & 1.49 & 1.49 \\
\hline 22 & Tyrosine & 6.91 & - \\
\hline 23 & 2-hydroxybutyrate & $1.19,2.28$ & 2.28 \\
\hline 24 & Citrate & 2.70 & 2.70 \\
\hline
\end{tabular}


Table 1. Cont.

\begin{tabular}{cccc}
\hline $\begin{array}{c}\text { Metabolite } \\
\text { Number }\end{array}$ & Metabolites & $\begin{array}{c}\text { Caco-2 } \\
\text { Chemical Shifts (ppm) }\end{array}$ & $\begin{array}{c}\text { >Caco-2 Treated with CAII } \\
\text { Chemical Shifts (ppm) }\end{array}$ \\
\hline 25 & Pyruvate & 2.37 & 2.37 \\
\hline 26 & Histidine & 7.11 & - \\
\hline 27 & S-Sulfocysteine & $3.48,3.66$ & $3.48,3.66$ \\
\hline 28 & O-phosphocholine & 4.17 & 4.17 \\
\hline 29 & Carnitine & 3.17 & 3.17 \\
\hline 30 & Valine & 1.05 & 1.05 \\
\hline 31 & Isoleucine, leucine & $0.94,0.97$ & $0.94,0.97$ \\
\hline 32 & Ethanolamine & $3.16,3.82$ & $3.16,3.82$ \\
\hline 33 & AMP & $4.01,4.15,4.36,6.15$ & $4.15,6.15$ \\
\hline
\end{tabular}

A further ${ }^{1} \mathrm{H}$ NMR run of Caco-2 cells treated with CAII was conducted (Figure 7) where metabolic changes were screened. A slight upfield shift was observed, suggesting a possible interaction of the cell metabolites with the calix[4]arene receptor.

Screening the metabolic changes as a result of CAII treatment showed reduced levels of glucose as well as water soluble metabolites such as lactate, acetate, hydroxybutyrate, and lysine as compared to the untreated cells. These changes suggest a shift in the metabolic pathway from homolactic to mixed acid formation (lactate, acetate). The outcome of this study revealed some changes in the metabolic profile of the Caco-2 cancer cell (Figure 8) resulting from the CAII treatment. These findings may add further biochemical data at the molecular level in colorectal cancer research, which could be useful in the exploration of cancer treatment.

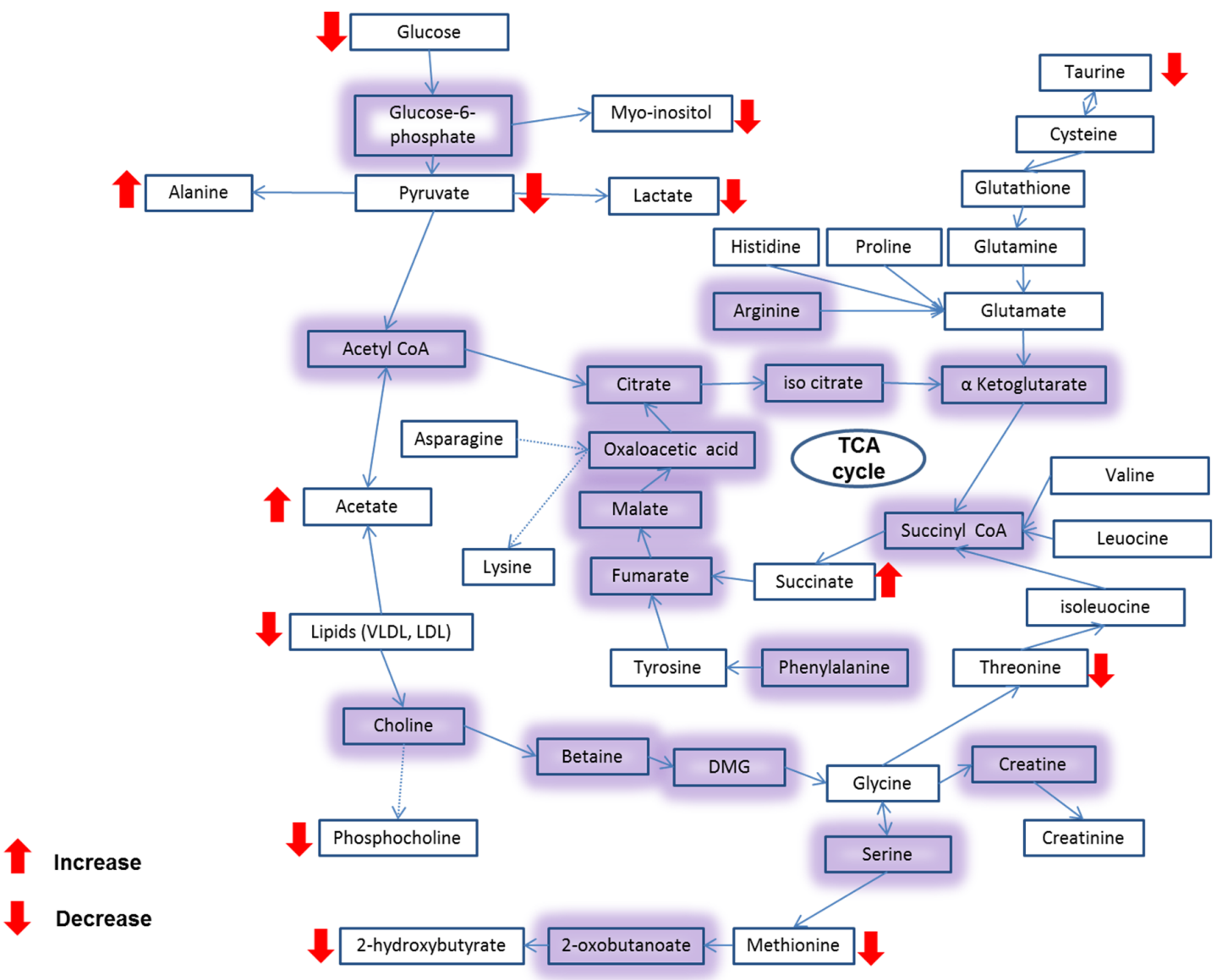

Figure 8. Schematic overview of the metabolic changes in CAII-treated Caco-2 cells. 


\subsection{Confocal Raman Spectroscopy Measurements}

Raman Spectroscopy measurements were performed on untreated and CAII-treated Caco-2 cells in order to monitor the effect of the applied calix[4]arene derivative on components of the cells. Figure 9 displays the Raman results of the untreated cancer cells versus the treated ones showing the overall cell response to the applied calix[4]arene receptor. Assignments along with the intensities of the Raman peaks that correspond to some regions that have biological significance are presented in Table 2. The regions of interest displaying the biochemical fingerprint composed of proteins, lipids, and nucleic acid backbone signals are shown in the 500 to $3000 \mathrm{~cm}^{-1}$ range. As shown in the spectra of both samples, the band attributed to the phospholipid components of the cell membrane in Caco- 2 cells at $1338 \mathrm{~cm}^{-1}$ is characterised by a lower intensity than that observed in the Raman spectrum of the CAII-treated cells (Table 2). Bands vibrating in 3055-2882 $\mathrm{cm}^{-1}$ appeared to be different in both spectra. Moreover, the blue shift observed in the protein peaks is an indication of a change in the characteristics of this biological material. Changes in the peak attributed to the $\mathrm{CH}_{2}$ of the lipid component of the membrane at $1440 \mathrm{~cm}^{-1}$ were observed as a result of Caco- 2 incubation with the CAII receptor.

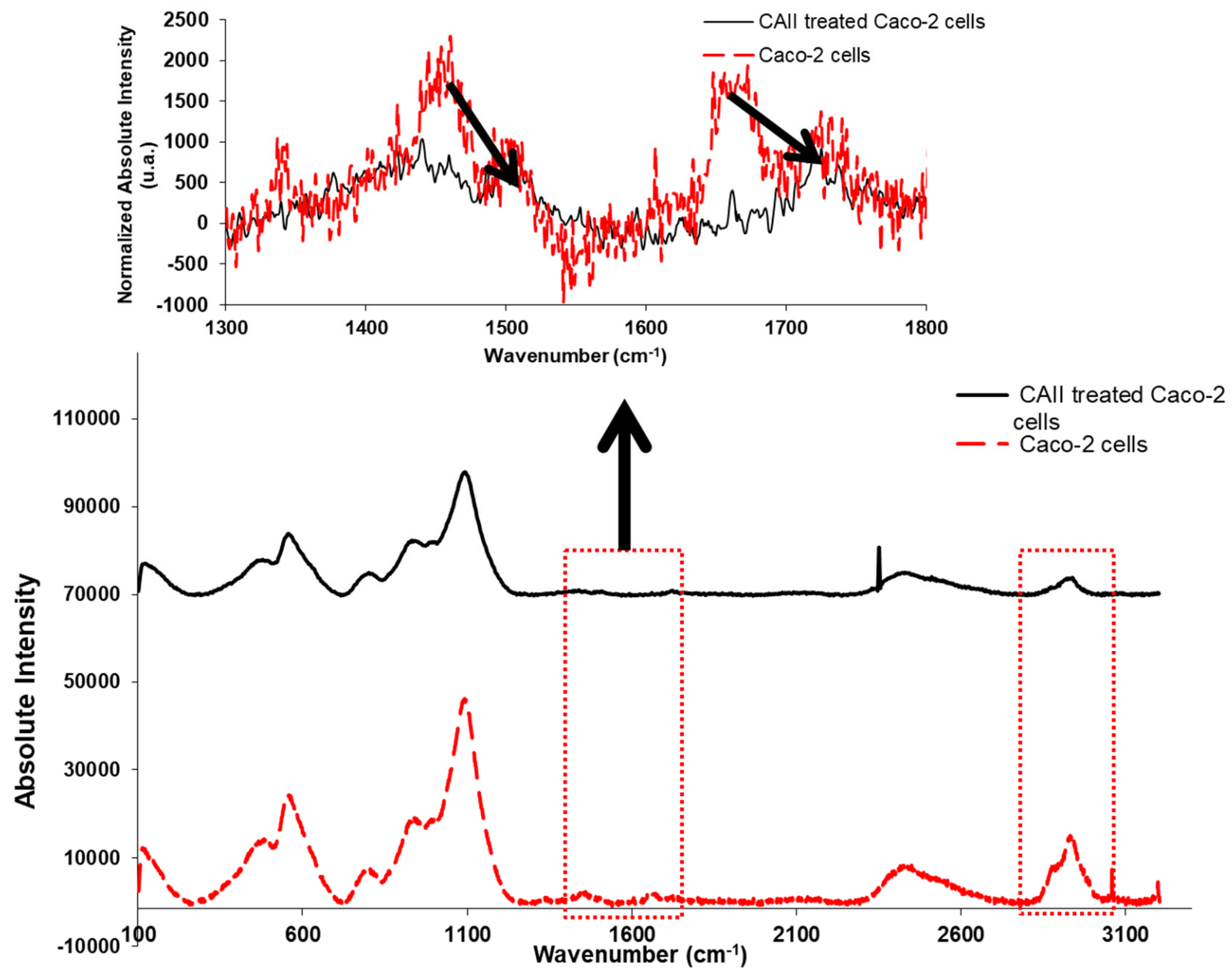

Figure 9. Raman spectra $\left(286-3201 \mathrm{~cm}^{-1}\right)$ of Caco-2 and $10 \mu \mathrm{M}$ CAII-treated Caco-2 cells incubated for $24 \mathrm{~h}$. 
Table 2. Intensity values at some regions of interests of Raman spectra for Caco-2 cells and CAIItreated Caco-2.

\begin{tabular}{cccc}
\hline Assignments & $\begin{array}{c}\text { Wavenumber } \\
\left(\mathbf{c m}^{-\mathbf{1}}\right)\end{array}$ & $\begin{array}{c}\text { Intensity } \\
\text { Caco-2 Cells }\end{array}$ & $\begin{array}{c}\text { Intensity } \\
\text { CAII-Treated Caco-2 Cells }\end{array}$ \\
\hline $\mathrm{C}=\mathrm{C}$ (aromatic) & 3055 & 885 & 85 \\
\hline $\mathrm{CH}_{3}$ (stretching) & 2971 & 6720 & 1204 \\
\hline $\mathrm{CH}_{2}$ (stretching) & 2882 & 8309 & 1480 \\
\hline $\mathrm{C}=\mathrm{O}$ (stretching) & 1728 & 913 & 591 \\
\hline Amide I & 1650 & 1162 & -28 \\
\hline $\begin{array}{c}\mathrm{CH}_{2} \text { deformation of } \\
\text { nucleic acids }\end{array}$ & 1450 & 1576 & 583 \\
\hline $\mathrm{CH}_{2}$ twist and bend & 1338 & 625 & 124 \\
\hline $\begin{array}{c}\text { PO } \\
\text { stretching }\end{array}$ & 1108 & 41,436 & 25,425 \\
\hline $\mathrm{C}-\mathrm{O}$ (ribose) & 982 & 17,719 & 11,463 \\
\hline $\begin{array}{c}\text { Skeletal mode of } \\
\text { polysaccharides }\end{array}$ & 939 & 18,311 & 12,195 \\
\hline $\begin{array}{c}\text { Cytosine and uracil } \\
\text { (stretching) }\end{array}$ & 789 & 6985 & 7398 \\
\hline$>\mathrm{S}-\mathrm{S}<$ (stretching) & 550 & 23,519 & 12,055 \\
\hline$>$ S-S< (stretching) & 511 & & 7169 \\
\hline
\end{tabular}

\section{Conclusions}

From the above discussion, the following was concluded:

(i) CAII inhibits the Caco-2 cell proliferation in a concentration-dependent manner. The compound mode of action is mediated by an apoptosis mechanism that is considered to be an important aspect in defeating cancer.

(ii) The MTT assay results demonstrate the anticancer effect of CAII against Caco-2 cells with an IC50 value of $19.02 \pm 0.04 \mu \mathrm{M}$, revealing the fast action mechanism of this receptor relative to other reported chemotherapeutic drugs.

(iii) Flow cytometry analysis shows that, at a starting dose of $10 \mu \mathrm{M}$, an apoptotic cascade in Caco-2 cells is observed. This cell death mechanism was corroborated by ${ }^{1} \mathrm{H}$ NMR and Raman spectroscopic analyses. Thus, the reduction of the level of water soluble metabolites treated with CAII as well as the phospholipid component of the cell membrane clearly indicate a change in the metabolic profile of the cancer cell following the treatment with the calix[4]-based receptor.

(iv) Raman studies provide evidence that the calix[4]arene-thioacetamide receptor interacts with the protein metabolites of Caco-2 cells. This is indeed an important aspect to highlight in this paper since it proves the effect of the applied anti-cancer agent on the protein transporters which play an essential role in the efflux mechanism of drugs, thus leaving the cells resistant to them.

Author Contributions: A.F.D.d.N., principal investigator of the work; N.A.H., carried out the experimental work and later on made an input on the biological aspect of the paper; S.Y.F., consultant in colorectal cancer who provided advice in several steps of the research. All authors have read and agreed to the published version of the manuscript.

Funding: Funding sources provided by Zeina El Eid from Lebanon.

Data Availability Statement: Not applicable. 
Acknowledgments: The authors are most grateful to Zeina El Eid (Lebanon) for providing generous financial assistance. Without her contribution, this research would not have been accomplished.

Conflicts of Interest: The authors declare no conflict of interests.

\section{References}

1. Den Bakker, C.M.; Schaafsma, F.G.; Huirne, J.A.F.; Consten, E.C.J.; Stockmann, H.B.A.C.; Rodenburg, C.J.; de Klerk, G.J.; Bonjer, H.J.; Anema, J.R. Cancer survivors' needs during various treatment phases after multimodal treatment for colon cancer-Is there a role for eHealth? BMC Cancer 2018, 18, 1207. [CrossRef]

2. Ouakrim, D.; Pizot, C.; Boniol, M.; Malvezzi, M.; Boniol, M.; Jenkins, M.; Bleiberg, H.; Autier, P. Trends in colorectal cancer mortality in Europe: Retrospective analysis of the WHO mortality database. BMJ 2015, 351, h4970. [CrossRef]

3. National Bowel Cancer Audits. 2016 Annual Report; National Health Service: London, UK, 2016.

4. Melina, A.; Mònica, S.S.; Mathieu, L.; Isabelle, S.; Ahmedin, J.; Freddie, B. Global patterns and trends in colorectal cancer incidence and mortality. Gut 2017, 66, 683-691.

5. Murphy, C.C.; Harlan, L.C.; Lund, J.L.; Lynch, C.F.; Geiger, A.M. Patterns of Colorectal Cancer Care in the United States: 1990-2010. J. Natl. Cancer Inst. 2015, 107, djv198. [CrossRef]

6. Agur, Z.; Arnon, R.; Schechter, B. Reduction of cytotoxicity to normal tissues by new regimens of phase-specific drugs. Math Biosci. 1988, 92, 1-15. [CrossRef]

7. Robella, M.; Vaira, M.; Argenziano, M.; Spagnolo, R.; Cavalli, R.; Borsano, A.; Zhang, Q.; Zhou, H.; Wu, J.; Tian, Y.; et al. Exploring the use of pegylated liposomal doxorubicin $(\operatorname{Caelyx}(\mathrm{R}))$ as pressurized intraperitoneal aerosol chemotherapy. Front. Pharmacol. 2019, 9, 2158-2166. [CrossRef]

8. Zhu, Y.; Zhang, M.; Luo, L.; Gill, M.R.; De Pace, C.; Battaglia, G.; Zhang, Q.; Zhou, H.; Wu, J.; Tian, Y.; et al. NF-kappaB hijacking theranostic $\mathrm{Pt}(11)$ complex in cancer therapy. Theranostics 2019, 9, 2158-2166. [CrossRef]

9. Zhang, X.; Qi, Z.; Yin, H.; Yang, G. Interaction between p53 and Ras signaling controls cisplatin resistance via HDAC4- and HIF-1alpha-mediated regulation of apoptosis and autophagy. Theranostics 2019, 9, 1096-1114. [CrossRef] [PubMed]

10. Ashwin, B.C.M.A.; Arun Baby, A.H.; Prakash, M.; Hochlaf, M.; Mareeswaran, P.M. A combined experimental and theoretical study on $p$-sulfonatocalix[4]arene encapsulated 7-methoxycoumarin. J. Org. Phys. Chem. 2018, 31, e3788. [CrossRef]

11. Nimse, S.B.; Kim, T. Biological applications of functionalized calixarenes. Chem. Soc. Rev. 2013, 42, 366-386. [CrossRef]

12. Baggetto, L.G.; Coleman, W.A.; Lazar, A.N.; Magnard, S.; Michaud, M.H. Calixarene Derivatives as Anticancer Agent. U.S. Patent Application No. 20100056482A1, 4 March 2010.

13. Pur, F.N.; Dilmaghani, K.A. Calixplatin: Novel potential anticancer agent based on the platinum complex with functionalized calixarene. J. Coord. Chem. 2014, 67, 440-448.

14. Da Silva, E.; Lazar, A.N.; Coleman, A.W. Biopharmaceutical applications of calixarenes. J. Drug Del. Sci. Tech. 2004, 14, 3-20. [CrossRef]

15. Uyar Arpaci, P.; Ozcan, F.; Omar, N.; Ozcan, F.; Ertul, S. Evaluation and biocompatibility of supramolecular calixarene on L-929 by real time cell analysis. In Proceedings of the IEEE 7th Internet, Conference Nanomaterials: Applications and Properties, Zatoka, Ukraine, 10-15 September 2017.

16. Dawn, A.; Yao, X.; Jiang, J.; Kumari, H. Assessment of the In Vitro toxicity of calixarenes and a metal seamid calixarene: A chemical pathway for clinical applications. Supramol. Chem. 2019, 31, 421-435. [CrossRef] [PubMed]

17. Shurpik, D.N.; Padnya, P.L.; Stoikov, I.I.; Craigg, P.J. Antimicrobial activity of calixarenes and related macrocycles. Molecules 2020, 25, 5145. [CrossRef]

18. Coleman, A.W.; Jebors, S.; Cecillon, S.; Perret, P.; Garin, D.; Marti-Battle, D.; Moulin, M. Toxicity and biodistribution of parasulfonato-calix[4]arene in mice. New J. Chem. 2008, 32, 780-782. [CrossRef]

19. Huliková, K.; Grobárová, V.; Křivohlavá, R.; Fišerová, A. Antitumor activity of N-acetyl-D-glucosamine-substituted glycoconjugates and combined therapy with keyhole limpet hemocyanin in B16F10 mouse melanoma model. Folia Microbiol. 2010, 55, 528-532. [CrossRef]

20. Nicholson, J.K.; Connelly, J.; Lindon, J.C.; Holmes, E. Metabonomics: A platform for studying drug toxicity and gene function. Nat. Rev. Drug Discov. 2002, 1, 153-161. [CrossRef]

21. Nicholson, J.K.; Wilson, I.D. Understanding 'Global' Systems Biology: Metabonomics and the Continuum of Metabolism. Nat. Rev. Drug Discov. 2003, 2, 668-676. [CrossRef]

22. Zhang, A.; Sun, H.; Xu, H.; Qiu, S.; Wang, X. Cell Metabolomics. OMICS 2013, 17, 495-501. [CrossRef]

23. Danil de Namor, A.F.; Pawlowski, T. A new calix[4]arene derivative and its ionic recognition for silver(i) and mercury(ii): The solvent effect. New J. Chem. 2011, 35, 375-384. [CrossRef]

24. Wong, R.S. Apoptosis in cancer: From pathogenesis to treatment. J. Exp. Clin. Cancer Res. 2011, 30, 87. [CrossRef]

25. McConkey, D.J. Therapy-induced apoptosis in primary tumors. Adv. Exp. Med. Biol. 2007, 608, 31-51. [PubMed]

26. Schmitt, J.M. Optical coherence tomography (OCT): A review. IEEE J. Sel. Top. Quantum. Electron. 1999, 5, 1205-1215. [CrossRef]

27. DiMilla, P.A.; Stone, J.A.; Quinn, J.A.; Albelda, S.M.; Lauffenburger, D.A. Maximal migration of human smooth muscle cells on fibronectin and type IV collagen occurs at an indermediate attachment strength. J. Cell. Biol. 1993, 122, 729-737. [CrossRef] [PubMed] 
28. Quan-Jun, Y.; Jun, B.; Li-Li, W.; Yong-Long, H.; Bin, L.; Qi, Y.; Yan, L.; Cheng, G.; Gen-Jin, Y. NMR-based metabolomics reveals distinct pathways mediated by curcumin in cachexia mice bearing CT26 tumor. RSC Adv. 2015, 5, 11766-11775. [CrossRef]

29. Arminan, A.; Palomino-Schatzlein, M.; Deladriere, C.; Arroyo-Crespo, J.J.; Vicente-Ruiz, S.; Vicent, M.J. Pineda-Lucena, A. Metabolomics facilitates the discrimination of the specific anti-cancer effects of free- and polymer-conjugated doxorubicin in breast cancer models. Biomaterials 2018, 162, 144-153. [CrossRef]

30. Lauri, I.; Savorani, F.; Iaccarino, N.; Zizza, P.; Pavone, L.M.; Novellino, E.; Engelsen, S.B.; Randazzo, A. Development of an Optimized Protocol for NMR Metabolomics Studies of Human Colon Cancer Cell Lines and First Insight from Testing of the Protocol Using DNA G-Quadruplex Ligands as Novel Anti-Cancer Drugs. Metabolites 2016, 6, 4. [CrossRef]

31. Halama, A. Metabolomics in cell cultureea strategy to study crucial metabolic pathways in cancer development and the response to treatment. Arch. Biochem. Biophys. 2014, 564, e100-e109. [CrossRef]

32. Wishart, D.S.; Jewison, T.; Guo, A.C.; Wilson, M.; Knox, C.; Liu, Y.; Djoumbou, Y.; Mandal, R.; Aziat, F.; Dong, E.; et al. HMDB 3.0- the human metabolome database in 2013. Nucleic. Acids Res. Spec. Publ. 2013, 41, D801-D807. [CrossRef] 